\title{
Refracting the "India idea" through the Prism of English Rhetoric: The Essays of Amartya Sen and Salman Rushdie
}

\section{Catherine Pesso-Miquel}

\section{CpenEdition}

\section{Journals}

Electronic version

URL: https://journals.openedition.org/ces/8700

DOI: $10.4000 /$ ces. 8700

ISSN: 2534-6695

\section{Publisher}

SEPC (Société d'études des pays du Commonwealth)

\section{Printed version}

Date of publication: 1 September 2009

Number of pages: $54-65$

ISSN: 2270-0633

\section{Electronic reference}

Catherine Pesso-Miquel, "Refracting the "India idea" through the Prism of English Rhetoric: The Essays of Amartya Sen and Salman Rushdie", Commonwealth Essays and Studies [Online], 32.1 | 2009, Online since 23 December 2021, connection on 17 February 2022. URL: http://journals.openedition.org/ces/ 8700 ; DOI: https://doi.org/10.4000/ces.8700

\section{(c) $(1) \&$}

Commonwealth Essays and Studies is licensed under a Licence Creative Commons Attribution - Pas d'Utilisation Commerciale - Pas de Modification 4.0 International. 


\section{Refracting the "India idea" through the Prism of English Rhetoric: The Essays of Amartya Sen and Salman Rushdie}

This article examines essays by Amartya Sen and Salman Rushdie addressing what Rushdie, inspired by Tagore, calls the "India idea". It focuses on the nature of the essays, their use of the English language, their exploration of Indian history and culture, and their spirited defence of the idea that a tolerant, heterodox, argumentative India existed a long time before English influence was brought to bear on it.

martya Sen, an Indian citizen, the winner of the Nobel prize for
economics in 1998, is also the author of many books and articles, a
number of which focus on India. This essay confronts a collection of his texts entitled An Argumentative Indian (2005) with Salman Rushdie's second collection of non-fiction, Step Across This Line. In spite of the numerous and obvious differences in nature and method distinguishing Sen's production from Rushdie's distinctively culture-oriented texts, one is struck by a convergence in ideas and spirit between the economist and the novelist, as if one could hear them engaging in an imaginary dialogue in which the most important and recurrent topic is what Rabindranath Tagore called "the idea of India" (Sen 349).

India has been a nation-state for over sixty years, but it remains a problematic entity that fascinates both Indian citizens and diasporic Indians trying to construct an identity, as well as scholars, whose powers of analysis and definition it challenges, to the point that its very existence is questioned. "Does India exist?" Rushdie wondered in 1987 (Rushdie, Homelands 26); "Is India Indian? Does it matter?” Arundhati Roy echoed in 1999 (Roy 148). The question remains open, and the proposed answers are highly controversial. Beyond wondering to what extent the viewpoints and the methods of Sen and Rushdie diverge, the focus here will be on the specific angle that the use of the English language can bring to such essays about the "India idea", and on the convergence of two differently brilliant minds engaged in illustrating a heterodox conception of the Indian nation.

Amartya Sen's The Argumentative Indian is subtitled Writings on Indian Culture, History and Identity, but within the book, from the first words of the preface, the "writings" are referred to as "essays". It is an elegantly built volume, containing four sections, with four essays in each of these. While every section has a specific focus, all deal with some aspect of India and its culture. Salman Rushdie's Step Across This Line is also divided into four parts, but represents a more heteroclite assemblage of columns, memoirs, essays, travel narratives and lectures. These different labels notwithstanding, most of the pieces collected in the Rushdie volume can be defined as "essays" in the noble sense of a text that exposes and defends a personal point of view, and tries to win listeners over 
through argumentative and persuasive rhetoric. Rushdie of course is very much aware of the permeability of the limits supposed to divide literary genres. His essays are imaginative, inventive and colourful, and in many of his novels, long intellectual developments could stand as essays in their own right, in Fury in particular (of course these passages reflect the characters' worldviews, and not necessarily the author's).

In his sixteenth essay Sen mentions a chapter he once published in a collective work, entitled "The Pattern of British Enterprise in India 1854-1914: A Causal Analysis", adding that "a small misprint" had rendered his title more intriguing, since the paper seemed to be "making the heady claim that [Sen] was presenting a 'casual' analysis" (Sen 335n). This anecdote is interesting because it symbolises the main difference between Rushdie's and Sen's approaches to essay writing. Sen is very thorough and scholarly while Rushdie's voice is brash, provocative, and blithe, very "casual" indeed. Amartya Sen is prudence itself, insisting on an unimpeachable scientific method, on the use of notes and indexes, and the following quote is a good example of his constant oratory precautions:

There is a good deal of empirical evidence that such thoughts had crossed the minds of many responsible people in Britain, but we still have to ask whether such perceptions constituted a significant economic and social phenomenon, and to what extent they affected the pattern of British investment in India. (Sen 335, emphasis added)

Rushdie's method is empirical, and he tends to impose his point of view and stand by it, sometimes to the point of provocation. An essay he wrote in 1997, for the fiftieth anniversary of Indias independence, notoriously claimed that Indian prose writing in English since Partition was "a more interesting body of work" than "most of what has been produced in [...] the so-called vernacular languages, during the same time", adding "Indo-Anglian' literature represents perhaps the most valuable contribution India has yet made to the world of books. The true Indian literature of the first postcolonial half century has been made in the language the British left behind" (Rushdie, "Damme" 50). He deleted the last sentence when this essay was first reproduced (as an introduction to his anthology of Indian writing) and later deleted the last two sentences when the same essay was collected in Step Across This Line, adding a footnote that acknowledged the "howls of protest and condemnation" triggered by his thesis "when first published in two slightly different versions", and yet he refused to give in, or withdraw his claim, defiantly asserting: "Readers are accordingly warned that mine is an improper view. Which doesn't necessarily mean it's wrong" (Rushdie, Step 147n).

Amartya Sen is precise and extremely scrupulous in his methods, whereas Rushdie discards any use of academic paraphernalia. Rushdie is often intensely personal, writing within the conventions of the autobiographical essay, whereas Sen prefers to be as impersonal as possible, apologizing for a few rare exceptions, as in his preface, where he points to the Bangladeshi component in his identity, 
visible in the pronoun 'we' he adopts in his essays instead of an impersonal 'they' (Sen xvii), or when he mentions his grandfather, a Sanskrit scholar and an author in his own right: "This is a general book on India, and should perhaps be uncompromisingly impersonal. However, I will take the liberty of talking a little, with due apology, about some personal memories" (Sen 45). Given his personal history, Rushdie is unfortunately not really in a position to separate the private from the public spheres, but it is undeniable that he enjoys the form of the autobiographical essay in which the reader is made to eavesdrop on his humorous, no-nonsense dialogue with himself or on his terse admonitions to himself.

Sen, who insists that his collected essays represent "an academic study done by a detached observer" (Sen xvii), makes liberal use of a double system of footnotes and endnotes, always fully citing his sources, whereas Rushdie's footnotes tend to be very wry, personal and anecdotic comments ${ }^{1}$. Even when quoting his own fiction Rushdie is blithely vague: "exile, it says somewhere in The Satanic Verses, is a dream of glorious return" (Rushdie, Step 183; the phrase appears in the fourth part of the novel, 205). Interestingly Rushdie has lately turned to more academic habits in his fiction, since The Enchantress of Florence (2008) comes complete with a bibliography.

Amartya Sen is an Indian but has long been a NRI, a "non resident Indian", even if he likes to boast that he never stays away from India for more than six months at a time. Shashi Tharoor jokes about this acronym in a chapter entitled "NRIs: 'Never Relinquished India' or 'Not Really Indian'?" (139) and he firmly places himself within the first category (158), to which Sen and Rushdie emphatically belong also, even if Rushdie is technically a British citizen and not an NRI:

My characters have frequently flown west from India, but in novel after novel their author's imagination has returned to it. This, perhaps, is what it means to love a country: that its shape is also yours, the shape of the way you think and feel and dream. That you can never really leave. (Rushdie, Step 180)

Like Sen, who uses the pronoun "we" (Sen xvii), Rushdie includes himself in his discourse on India: "I say 'our' because I write as an Indian man born and bred, who loves India deeply", adding, "If I take pride in India's strengths, then India's sins must be mine as well" (Rushdie, Step 344). He describes his novel writing as "literary land reclamation" (180), and confesses that "the delight with which Indian readers clasped the book to themselves, the passion with which they, in turn, claimed [him], remains the most precious memory of [his] writing life" (181).

Yet Salman Rushdie famously feels more than just Indian, he feels "hybrid" and "half-and-half", to use favourite epithets of his, and in 1993 he recognized, in the experience of other writers, his own predicament. Commenting on the fate of the francophone Algerian writer Tahar Djaout, assassinated by Islamist fanatics,

1. See his notes on pages $8,32,50,246,270$. Rare exceptions exist, as on page 374 . 
he noted that he "felt close to [Djaout's] plurality of self as well as tongue, and to his vulnerability", adding, "Those who embrace difference are always in danger from the apostles of purity" (Rushdie, Step 249). Djaout's fate and his use of French echoed the danger that threatened Rushdie and his use of the English language, consistently presented as an Indian language, re-appropriated by the former colonised subjects (see Rushdie, Homelands 17). That might be another difference between Sen and Rushdie, the latter feeling that he has to justify his use of English by cross-pollinating it, hybridising it, "tropicalizing" it with playful, inventive zest and wit. His defiant, colourful language makes use of clipped phrases and powerful images, neologisms, tropes and compound words and phrases. $\mathrm{He}$ was thus able to dismiss the fatwa threat with a contemptuous image, as "the blackest of black comedies - a circus sideshow enacted by murderous clowns" (Rushdie, Step 234). He also made use of pop culture to illustrate once again one of his most favourite, urgent themes, that of impurity (Rushdie, Step 268). In an essay written (and entitled) "In Defence of the Novel, Yet Again", dating from 1996, his language is particularly witty and mordant as he tears to pieces the pompous arguments of Professor George Steiner, who heralds in the same breath "that tasty old chestnut, the death of the Novel", the death of the Reader, doomed to become "some sort of super-nerd," and the death of the Book (50). Rushdie mentions an image created by Will Self, according to which there exists only an inadequate sum total of sanity available to the human race, dooming many to insanity, "as if we were all sleeping in a bed covered by a blanket - of sanity - that wasn't quite big enough to cover us all", and he comments Self's trope:

It is a richly comic idea, and it recurs in professor Steiner's zaniest argument, which he offers with a perfectly straight face - that at any given moment, there exists a total quantum of creative talent, and at present the lure of the cinema, television, and even of advertising is pulling the blanket of genius away from the novel, which consequently lies exposed, shivering in its pajamas in the depths of our cultural winter. (Rushdie, Step 53)

This playful, irreverent and imaginative way of addressing serious subjects causes Rushdie to alight with glee on the appalling absurdity of certain contemporary theories and practices. About creationism in the USA, in the state of Kansas more precisely, Rushdie shrugs: "this stuff would be funny if it weren't so unfunny", and he asserts flippantly that "Gobbledygook is back in style. The pull of stupidity grows everywhere more powerful. The young speak of the spiritual life as if it were a fashion accessory" (281). Nevertheless Rushdie's style is also often more conventionally rhetorical, as when he uses ringing tones and a stirring ternary rhythm to deplore the rise of Hindu nationalism, seeing it as "the triumph of sectarianism over secularism, of hatred over fellowship, of ugliness over love"(203).

Amartya Sen's language does not indulge in the fanciful and playful twists with which Rushdie fertilizes the English language. Sen's use of language is never 
flamboyant, provocative, idiosyncratic, self-conscious or fore-grounded; it is always elegant and limpid, very fluid, an intellectual gem of precision, unpretentiousness, intelligence. It expresses complex ideas and nuances in simple, luminous terms. There is none of the fussiness and sycophancy of certain contemporary jargons that imitate a particular theory or thinker, and then become so easily dated. No fuss, but no flatness either. Sen's style is more like Gaudi's understated, elegant Casa Milà than like the cold, soulless functionality of Le Corbusier's creations. Sen quietly takes his place in the cultivated dialogue between philosophers, writers and poets that echoes across the centuries. He comments on and answers their arguments in the same elevated, literary register. To give one example taken from an essay first published in 2000, Sen quotes Yeats's reaction to Nietzsche's pessimism in The Genealogy of Morals: "But why does Nietzsche think the night has no stars, nothing but bats and owls and the insane moon?" (Yeats in Sen 273). Then, commenting on the lack of critical assessment among the celebrations for the Millenium, the apparent general obliviousness of the world to the horrors of the twentieth century and the uncertainties of the future, Sen winks back at the Irish poet, adding the definite articles signalling the identifiability of the words already quoted, thus creating a jaunty, tripping anapaestic rhythm: "As the century and the second Gregorian millenium came to an end, [...] the lights of celebratory glory not only drowned the stars but also the bats and the owls and the insane moon" (274).

In different ways both Rushdie and Sen have pursued a tradition of non fiction Indian writing in English, of which Gandhi and Nehru, as Sunil Khilnani argues, were the early creators. Gandhi and Nehru exploited "the infinite adaptability of the language of the colonisers" (Khilnani, in Mehrotra 156), its "unchasteness", its propensity to absorb many foreign words. Like Urdu, it was "an amalgam, a synthesis of various languages", a quality that made it "dynamic" and "vital", unlike Hindi, a chaste and pure language, a "dead coin" "not soiled by daily use" (155). Rushdie developed much the same arguments about the adaptability of Urdu, "[his] own mother-tongue, the camp-argot of the country's earlier Muslim conquerors, [which] was also an immigrant language, forged out of a blend between the conqueror's imported tongue and the local languages they encountered", and of English, which "has become an Indian language", and which, "like Urdu and unlike all other Indian languages, has no regional base" but "has emphatically come to stay" (Rushdie, Step 149). Gandhi and Nehru, "central figures [...] in the long, uneasy task of making English an Indian language" (Khilnani, in Mehrotra 135), showed "how the language could be a tool of insubordination and, ultimately, freedom": "no two Indians exemplified so vividly the extent to which politics is words - a way of structuring human relations through the fragile architecture of language" (136). Nehru and Gandhi used the English language to help wrench an independent India out of the grasp of its imperialist conquerors; Rushdie and Sen used it partly to help define and defend the "India-idea", the unique quality of the Indian nation-state. 
Amartya Sen likes to quote Rabindranath Tagore's "visionary statement" "that the 'idea of India' itself militates 'against the intense consciousness of the separateness of one's own people from others" (Sen 72 and 349). He also refers several times to Sunil Khilnani's book The Idea of India, first published in 1997, in the new edition of which the author explains:

The idea of India is not homogenous and univocal. In fact no single idea can possibly hope to capture the many energies, angers, and hopes of one billion Indians; [i] t may seem obtuse, even hubristic, to speak of the idea of India. But one purpose of my book is to excavate the conception that provided the intellectual and practical underpinnings of modern India, that gave it its distinctive identity over the past half-century, and that kept it, unlike so many other new states, democratic, tolerant, and open-minded. (Khilnani, Idea xv)

In the same year, 1997, Salman Rushdie wrote an essay celebrating India's fiftieth anniversary in which he quoted Churchill's remark about India not being a nation but just "an abstraction", and John Kenneth Galbraith, who "more affectionately, and more memorably, described it as "functioning anarchy". Both of them, he concluded, "had underestimated the strength of the India-idea", "the thing which has survived all that history could throw at it" (Rushdie, Step 163-164). In exactly the same vein, Shashi Tharoor scoffed at how Churchill once "barked" that "India is merely a geographical expression", "no more a single country than the Equator"; Tharoor preferred the lyrical homage to India that Nehru penned in his book The Discovery of India (1946):

[India is] a bundle of contradictions held together by strong but invisible threads. Overwhelmed again and again her spirit was never conquered, and today when she appears to be a plaything of a proud conqueror, she remains unsubdued and unconquered. About her there is the elusive quality of a legend of long ago; some enchantment seems to have held her mind. She is a myth and an idea, a dream and a vision, and yet very real and present and pervasive. (Nehru, in Tharoor 7)

Sen is impressed by the point which "[Tharoor] makes powerfully, i.e. that 'the only possible idea of India is that of a nation greater than the sum of its parts" (Tharoor 5, quoted in Sen 57n).

Both Sen and Rushdie highly value secularism (in the Indian usage of the word ${ }^{2}$ ), plurality, and heterodoxy among the characteristics which have contributed to making India what it is, and to giving it a very specific destiny among ex-colonies. But Amartya Sen is worried that Indian secularism has come under violent attack from many quarters, not just from Hindu nationalism, and he has identified at least six distinct lines of arguments voicing scepticism against secularism. To counter one of them, based on the alleged priority of the Hindu

2. In India secularism focuses on neutrality and equality of treatment, or "equidistance", between state institutions and all religions, whereas in the West, in France in particular, secularism or "laïcité" focuses on strict separation of state and church(es) and on "prohibition of religious associations in state activities" (Sen 19). 
element within the national identity, Sen insists on "India's immense religious diversity", which is not only a question of Hinduism versus many other faiths, but also a recognition of "the divergences within Hinduism itself", the enormous gamut of forms Hinduism can take, including agnosticism (Sen 309). Rushdie, both because of his Muslim background, and his own reasons for being wary of Islamism, tends to use the same kind of arguments when he insists on the diversity of faiths and beliefs, and on the courage of the voices of dissent raised in defence of secularism, or of atheism, within Islam. While Rushdie, in November 2001, insisted that 9/11 was indeed "about Islam", he was careful to point out that this was not "to go along with Samuel Huntington's thesis about the 'clash of civilizations', for the simple reason that the Islamists' project is turned [...] also against their fellow-Islamists" (Rushdie, Step 340). In 1993 he had voiced concern because the Western media tended to give great publicity to stories of Islamist terrorism aimed at the West, but hardly paid attention to cases of domestic terrorism in India or in Muslim countries. At best the latter stories are "tucked away near the bottom of an inside page" in the western newspapers. Rushdie insists that secularism is "the fanatics' Enemy Number One", and that the West should be attentive to "the Muslim world's best, most honorable voices: its voices of dissent” (Rushdie, Step 239).

Amartya Sen argues that Hindu fundamentalism is more a political agenda than a religious one, and that one of the strategies of the Hindutva movement has been to rewrite history textbooks in order to create a "narrowly Hinduized view of Indian history" capable of appealing to members of the Indian diaspora, whose financial support is sought after (Sen 63): "The high ground of history is certainly not comfortable for a Hindu sectarian outlook, which is one reason why there has been such a flurry of attempts by political fanatics to rewrite Indian history, which has produced much drama and some farce" (Sen 57). Hindu nationalists try to "miniaturize" India, warns Sen, to "incarcerate it" within the confining limits of a "narrow box" (xii), but unfortunately they are helped in this enterprise by the ignorance and reductionism of westerners and many international journalists, who portray India as "a mainly Hindu country", a statement which confuses sheer numerical classification with beliefs, since "Hinduism", far from being reduced to the bigoted agenda of Hindu nationalist parties and paramilitary organisations, includes an endless variety of forms of worship, and even agnosticism and atheism. This reductionism attracts “intellectual simplifiers' like Samuel Huntington", "who places India firmly in the category of 'the Hindu civilization", ignoring the fact that India has the third largest Muslim population in the world after Indonesia and Pakistan and the fact that "nearly every country in Huntington's definition of 'the Islamic civilization' has far fewer Muslims than India has" (Sen 54). Unlike Rushdie's more flamboyant and sarcastic phrasings, Sen's protests against Huntington are couched in a moderate and argumentative language, but 
the indictment of Huntington, and the barely veiled contempt and anger, are the same.

The West tends to dismiss the Indian intellectual tradition as mysticism and imbued with an "impressive religiosity" (Sen 25), despite India's early mastery of mathematics and astronomy, and despite its vigorous tradition of scepticism and agnosticism (see Sen 164-165). Thus, long before Montaigne started wondering what he really knew, the Vedas expressed their own version of his famous "que sais-je?":

Who really knows? Who will here proclaim it? [...] Whence is this creation? The gods came afterwards, with the creation of this universe. Who then knows whence it has arisen? Whence this creation has arisen - perhaps it formed itself, or perhaps it did not - the one who looks down on it, in the highest heaven, only he knows - or perhaps he does not know. (Rig Veda 10, 129, in Sen 22)

Sen deplores the fact that Indian religious literature, seen as quintessentially different from Western secularist writings, attracts all the limelight in the West, while "other Indian writing, including India's long history of heterodoxy", is ignored, and yet "Sanskrit and Pāli have a larger atheistic and agnostic literature than exists in any other classical tradition" (285).

Rushdie, for his part, quotes Naipaul's opinion that "thoughtful men" in India "have preferred to turn their backs on the here and now", i.e. on the stuff of which Western novels are made, since "the novel is part of that Western concern with the condition of men, a response to the here and now". Rushdie often has little patience with Naipaul, and here again he unambiguously rejects his assertion: "[In India] for every unworldly seeker for the ancient wisdoms of the east, there is a clear-eyed witness responding to the here and now in precisely that fashion which Naipaul inaccurately calls uniquely Western" (Rushdie, Step 157). Rushdie also recalls how doubt could reign within enlightened western minds, like that of Diderot, torn between his mind and his "heart", between "atheistic, materialistic rationalism" and "a profound need for spiritual and moral depth" (215), or like Dostoevsky, "agonized about the existence in his heart of absolute faith and absolute unbelief" (216).

Huntington, who obviously aggravates Sen as much as Rushdie, is a good example of the Western tendency to confiscate rationality and enlightenment, and to forget that many achievements of "other civilizations" occurred long before Europe happened to reach the same results. The Chinese were printing texts on paper centuries before Gütenberg came into the world. Both Rushdie and Sen explore Indian history to defend the idea that a multiple, tolerant, heteroglossic and heterodox India existed a long time before English influence was brought to bear on it, an idea that most Westerners, raised on the illusion that they hold a monopoly of contradictory debates and democracy, find difficult to accept. Salman Rushdie's fiction provides another medium for this exploration, particularly his latest novel, The Enchantress of Florence, in which he creates his own fictitious version of the broad-minded, curious and tolerant Mughal Emperor, Akbar, 
who also happens to be one of Amartya Sen's favourite historical figures, along with Emperor Ashoka, who in the third century BCE championed tolerance, demanding "basic freedoms for all" without excluding "the forest people" or "women and slaves, as Aristotle did" (Sen 284).

Cutting across the absurd line of demarcation born of Partition, Rushdie makes the same point about Bengalis in a letter to Taslima Nasreen dated July 1994:

Bengali culture - and I mean the culture of Bangladesh as well as Indian Bengal - has always prided itself on its openness, its freedom to think and argue, its intellectual disputatiousness, its lack of bigotry. [...] Bengalis have always understood that free expression is not only a Western value; it is one of their own great treasures too. It is that treasure-house, the treasure-house of the intelligence, the imagination, and the word, that [Taslima's] opponents are trying to loot. (Rushdie, Step 253)

Amartya Sen argues that "a rich tradition of argument" "has helped to make heterodoxy the natural state of affairs in India", "particularly relevant to the development of democracy in India" (Sen 12), even if many Westerners are convinced that "the Indian commitment to democracy [can be attributed] simply to the impact of British influence" (ibidem), ignoring the fact that this influence seems not to have had any impact on "a hundred other countries that emerged from an empire on which the sun used not to set" (ibidem). Rushdie criticises the fact that European Union leaders "pay lip service to the Enlightenment ideals ("free expression, human rights, the right to dissent, the importance of the separation of Church and State") while sacrificing freedom to "the powerful banalities": "trade, money, guns, power" (Rushdie, Step 258); for his part Sen evokes Jonathan Glover, an Oxford philosopher whose analyses of the twentieth century he admires, but whose "willingness to join the fashionable chorus of attacks on the Enlightenment" he finds "deeply puzzling" (Sen 275).

The Western "idea of India", still imbued with prejudice and colonialism, creates the picture of a mystic, irrational India turning its back on modernity, and this image plays into the hands and strategies of both Hindu nationalists in India and of fundamentalist Muslims in Pakistan, where the Taliban, fleeing from Afghanistan, are currently gaining ground, and appealing to the populace by creating the myth that Islam should be posited against the West, against modernity and Enlightenment, against reason, the myth that cruel punishments and dire retribution are more intrinsically Islamic than tolerance and forgiveness are. Rushdie recounts dreadful murders perpetrated by Islamist fundamentalists in Sivas, Turkey, in 1993, not against atheists or agnostics but against secularist writers (Rushdie, Step 236). Both Sen and Rushdie agree that Hindu chauvinists should not be allowed to confiscate the idea of India, just as Islamist fundamentalists should not be allowed to confiscate the idea of Pakistan. Indeed in 2009, since the agreement between the Taliban and the Pakistani Prime Minister, the danger 
has concerned much more concrete issues: the territory and nation of Pakistan, and its nuclear armaments, not only the realm of ideology.

The idea of India as understood by Rushdie and Sen necessarily includes plurality and mutual influences, and the circulation of ideas, as opposed to purity and parochialism. As Sen puts it, "ideas as well as people have moved across India's borders over thousands of years, enriching India as well as the rest of the world" (Sen 86). "Europe would have been much poorer if it had not accepted the globalization of mathematics, science and technology in the tenth century, argues Sen (346), and Rushdie concurs. Writing about frontiers and walls, inclusion and exclusion, Rushdie evokes Sen: "As the economics Nobel laureate Professor Amartya Sen has said, the problem is not globalization. The problem is a fair distribution of resources in a globalized world" (Rushdie, Step 356 ${ }^{3}$ ). Therefore difference should be accepted and imported from without, but also accepted within the national boundaries, and even within the self: plurality and multiplicity stand staunchly posited against singularity, authenticity, purity. Sen, using the same kind of reasoning as Amin Maalouf, the Franco-Lebanese author of In the Name of Identity, argues: "Identity is a quintessentially plural concept, with varying relevance of different identities in distinct contexts" (Sen $\left.352^{4}\right)$.

Rushdie also argued that the most important component within the "idea of India" was plurality and multiplicity. If different Indians have very different ideas about exactly what the words "Indian identity" mean, it is also because all of them are a multiplicity of selves, because none of them can be reduced to a single, singular identity:

In the modern age, we have come to understand our own selves as composites, often contradictory, even internally incompatible. We have understood that each of us is many different people. [...] The nineteenth century concept of the integrated self has been replaced by this jostling crowd of "I"'s. [...] I agree with my many selves to call all of them "me". This is the best way to grasp the idea of India. India has taken the modern view of the self and enlarged it to encompass almost one billion souls. The selfhood of India is so capacious, so elastic, that it manages to accommodate one billion kinds of difference. It agrees with its billion selves to call all of them "Indian". (Rushdie, Step 164)

What both Rushdie and Sen agree to combat is any cheap exoticism by which the West might try to "miniaturize" and trivialize India. Reflecting on translation, Vladimir Nabokov had identified "three grades of evil [...] in the strange world of verbal transmigration": errors due to the translator's ignorance, the fact of skipping whole passages deemed obscure or obscene, and finally the fact of seeking to

3. An idea he had long ago made his, as can be seen in a footnote to a March 1999 essay on globalization that does not mention Sen: "American culture isn't the enemy. Globalization itself isn't the problem; the inequitable distribution of global resources is" (Rushdie, Step 269n).

4. See also Amartya Sen's Identity and Violence. 
improve the original text, "vilely beautifying" it "in such a fashion as to conform to the notions and prejudices of a given public" (quoted in Rushdie, Step 375). Quoting these remarks by Nabokov, Rushdie applied them to his own project of "translating' the great subject of India into English" (374) and explained that "the exoticization of India, its 'vile beautification", had to be avoided at all costs: "Now, at last, this kind of fake glamorizing is coming to an end, and the India of elephants, tigers, peacocks, emeralds, and dancing girls is being laid to rest" (375). Amartya Sen conducts his own condemnation of "exoticist readings of India" in his seventh essay, "Indian Traditions and the Western imagination" (Sen 139-160).

Salman Rushdie and Amartya Sen are unfashionably and staunchly in favour of Enlightenment. Like Montaigne, they admire and protect scepticism and the freedom of expressing doubt in the face of orthodox, absolutist minds. Wresting the mastery and monopoly of the English language away from the grasp of the former British colonisers, they contribute, in the Indian argumentative tradition, to proving Yeats wrong, the Yeats who in a letter to Sir William Rothenstein (1935) claimed that "Tagore does not know English, no Indian knows English" (Sen 95). Rushdie and Sen belong to that "generation of gifted Indian writers in English [who] is bringing into English their many different versions of the Indian reality" (Rushdie, Step 375). Their essays provide an invaluable defence of the "India idea" against its enemies within India as well as against the arrogant condescendence of the West.

Catherine PESSO-MIQUEL

University of Lyon 2

\section{Works Cited}

Khilnani, Sunil. The Idea of India. 1997. London: Penguin, extended edn 2003.

- "Gandhi and Nehru. The Uses of English", in Mehrotra, Arvind K. (ed.). A History of Indian Literature in English. New York: Columbia UP, 2003: 135-156.

MaAlouf, Amin. Les Identités meurtrières. Paris : Grasset, 1998. Translated into English as In the Name of Identity. New York: Arcade Publishing, 2000.

Menrotra, Arvind K. (ed.). A History of Indian Literature in English. New York: Columbia UP, 2003.

Roy, Arundhati. The Cost of Living. London: Flamingo, 1999.

RushdiE, Salman. Imaginary Homelands. London: Granta Books, 1991.

— "Damme, this is the Oriental scene for you!". The New Yorker (23 June 1997): 50-61.

— The Satanic Verses. 1988. New York: Viking, 1989.

- Step Across This Line. New York: Random House, 2002.

— and E. West (eds.). The Vintage Book of Indian Writing 1947-1997. New York: Vintage, 1997. 
SEN, Amartya. The Argumentative Indian: Writings on Indian Culture, History and Identity. 2005. London: Penguin, 2006.

- Identity and Violence. London: Allen Lane, 2006.

TAgore, Rabindranath. Letters to a Friend. With essays by C.F. Andrews. London: Allen and Unwin, 1928.

Tharoor, Shashi. India, from Midnight to the Millenium and Beyond. New York: Arcade, 1997. 